\title{
Lifestyle-related cardiovascular risk factors among adults in Delta State, Nigeria using WHO STEPS approach: prevalence and rural- urban differences
}

\author{
Umuerri E.M.
}

\begin{abstract}
Objective: To describe the prevalence and rural-urban differences in lifestyle-related cardiovascular risk factors.
\end{abstract}

Method: A cross-sectional survey of apparently healthy adults in an urban and a rural community in Delta State, Nigeria using the WHO STEPS questionnaire. Ethical approval was granted by the Delta State University Teaching Hospital.

Results: Of the 866 respondents, 56\% were urban dwellers and 44\% were males. The mean age was 42.5( \pm 16.05$)$ years. The prevalence of current smokers was $13.6 \%$. It was significantly higher among rural dwellers $(22.3 \%$ vs $6.8 \%, \mathrm{p}<0.001)$. Alcohol was consumed by $58.5 \%$ of the respondents in the last 12 months; rural more than urban dwellers $(79.5 \%$ vs $42.1 \%, \mathrm{p}<0.001)$. About $75 \%$ of the respondents ate $<5$ servings / portions of fruits daily. This was significantly higher among rural dwellers $(83.7 \%$ vs $67.4 \%$, $\mathrm{p}<0.001)$. Table salt was added to cooked food by $30.8 \%$ of the respondents. The rural-urban difference was not significant. In a typical week, $40.2 \%$ of respondents do not walk or ride a bicycle continuously for at least 10 minutes to-and-from places; urban (47.6\%) more than rural $(30.7 \%)$ dwellers $(\mathrm{p}<0.001)$.

Conclusion: Lifestyle-related cardiovascular risk factors are common in this study; more so in the rural setting. There is a need to increase cardiovascular health education and promotion activities.

Keywords: Lifestyle, cardiovascular risk factors, adults, WHO STEPS

Correspondence author

Umuerri E.M.

http://orcid.org/0000-0001-8372-8328

E-mail: umuerriejiro@gmail.com

Department of Medicine, Delta State University Teaching Hospital, Oghara, Nigeria

Delta State University, Abraka, Nigeria.

Research Journal of Health Sciences subscribed to terms and conditions of Open Access publication. Articles are distributed under the terms of Creative Commons Licence (CC BY-NC-ND 4.0). (http://creativecommons.org/licences/by-nc-nd/4.0).

http://dx.doi.org/10.4314/rejhs.v7i2.3 


\title{
Facteurs de risque cardiovasculaires liés au mode de vie chez les adultes de l'État de Delta, au Nigeria, selon l'approche STEPS de WHO: prévalence et différences entre zones urbaines et zones rurales
}

\author{
Umuerri E.M.
}

\section{Resume}

Objectif: Décrire la prévalence et les différences rurales-urbaines des facteurs de risque cardiovasculaires liés au mode de vie.

Méthode: Une enquête transversale sur des adultes apparemment en bonne santé dans une communauté urbaine et rurale de l'État de Delta, au Nigéria, à l'aide du questionnaire STEPS de WHO. L'approbation éthique a été accordée par l'hôpital universitaire de la Delta State.

Résultats: Sur les 866 répondants, $56 \%$ étaient des citadins et $44 \%$ des hommes. L'âge moyen était de $42,5( \pm 16,05)$ ans. La prévalence des fumeurs actuels était de 13,6\%. Il était significativement plus élevé chez les ruraux ( $22,3 \%$ vs $6,8 \%, p<0,001) .58,5 \%$ des répondants ont consommé de l'alcool au cours des 12 derniers mois; les ruraux plus que les citadins $(79,5 \%$ vs $42,1 \%$, p <0,001). Environ $75 \%$ des répondants ont mangé $<5$ portions / portions de fruits par jour. Ce taux était significativement plus élevé chez les habitants des zones rurales $(83,7 \%$ contre $67,4 \%, p<0,001)$. Le sel de table a été ajouté aux aliments cuits par $30,8 \%$ des répondants. La différence entre zones rurales et zones urbaines n'était pas significative. Au cours d'une semaine typique, $40,2 \%$ des répondants ne marchent pas et ne font pas de vélo de façon continue pendant au moins 10 minutes aller-retour; citadins $(47,6 \%)$ plus que les ruraux $(30,7 \%)(\mathrm{p}<0,001)$.

Conclusion: les facteurs de risque cardiovasculaires liés au mode de vie sont courants dans cette étude; plus encore en milieu rural. Il est nécessaire d'accroître les activités d'éducation et de promotion de la santé cardiovasculaire.

Mots-clés: Mode de vie, facteurs de risque cardiovasculaires, adultes, STEPS de WHO

\author{
Auteur principal \\ Umuerri E.M. \\ http://orcid.org/0000-0001-8372-8328 \\ E-mail: umuerriejiro@gmail.com
}

Department of Medicine, Delta State University Teaching Hospital, Oghara, Nigeria

Delta State University, Abraka, Nigeria. 


\section{INTRODUCTION}

Notwithstanding advances and innovations in healthcare in the $21^{\text {st }}$ century, cardiovascular disease (CVD) remains a substantial contributor to the global health burden (1-3). With approximately 18 million deaths annually, CVD has maintained the status of the foremost cause of premature deaths worldwide, chiefly from stroke and ischaemic heart disease (1). However, the spread of the global CVD burden is inequitable (4-6). Unlike high-income countries, the burden of the disease is significantly mounting in low- and middleincome countries (LMIC) (4-7). Indeed, more than three-quarters of the death burden from CVD worldwide occur in the economically disadvantaged LMIC (1).

The growing CVD burden in LMIC may be partly accounted for by rapid urbanization and 'westernization' (8-10). One of the adverse effects of urbanization is the adoption of unhealthy lifestyles. Indeed, rapid urbanization is accompanied by behaviours that put cardiovascular health at risks such as adoption of unhealthy dietary practices, sedentary lifestyle, tobacco smoking and harmful consumption of alcohol. High blood pressure, type 2 diabetes mellitus, dyslipidaemia and obesity are also significant risk factors for CVD and are often lifestyle related. However, with technological advancement and the advent of mass media, there is a gradual shift to urbanized lifestyle even in rural areas.

Data comparing the behavioural cardiovascular risk factors among urban and rural dwellers in Nigeria are limited. This paper aims to describe the prevalence and rural-urban differences in lifestyle-related cardiovascular risk factors in Delta State, Nigeria.

\section{MATERIALS AND METHOD}

This was a descriptive cross-sectional survey of apparently healthy adults in Delta State, Nigeria using a multistage sampling technique. The random selection of two of the three senatorial districts in Delta State was by balloting. After that, one study site was selected from each of the chosen senatorial district using the convenience sampling method. The urban setting, Warri, is a densely populated city located in Delta South senatorial district with latitudes between $5^{\circ} 31^{\prime} \mathrm{N}$ and $5^{\circ} 45^{\prime} \mathrm{E}$. The metropolis is the commercial centre and oil hub of Delta State. Warri is home to one of Nigeria's petroleum refineries. Other national and multinational oil and gas companies are across the City. Warri is also home to a seaport, an airport, a steel manufacturing company and the Federal University of Petroleum Resources.

On the other hand, the rural setting, Jesse, is sparsely populated. Located on a 500 square kilometres area in Delta Central senatorial district, Jesse lies between latitudes $5^{\circ} .15^{\prime}$ and $6^{\circ} 00^{\prime} \mathrm{N}$ and longitudes $5^{\circ} .40^{\prime}$ and $6^{\circ} .25^{\prime} \mathrm{E}$. It is an agrarian community, and most of the farmers engage in subsistence farming. Although Jesse is an oil-rich community like Warri, only oil mining activities take place there.

A two-stage clustering sampling technique was employed to recruit study participants from each of the study sites. Wards were selected from each of the study site using simple random sampling. After that, streets were selected from a sampling frame (list of streets in the chosen wards) by simple random sampling technique. Each selected street was regarded as a cluster and participants recruited from households until sample size was reached. Recruited study participants were apparently healthy adults aged 18 years and above who have lived in the study site for at least one (1) year. Adult residents who have lived less than one year, visitors to the study site and eligible but nonconsenting individuals were excluded from the study.

The minimum sample size for each study site was determined using the Cochran formula (n $\left.=1.96^{2} p(1-p) / d^{2}\right)$, assuming a $95 \%$ confidence interval and $\alpha$ of 0.05 . Hypertension is a prevalent modifiable cardiovascular risk factor in Nigeria. To calculate the minimum sample size, the pooled prevalence of hypertension between 2000 and 2009 of $22.5 \%$ was used (11).

Ethical approval was obtained from the Health Research Ethics Committee of the Delta State University Teaching Hospital (DELSUTH), Oghara before commencement of the survey. Participation in the study was entirely voluntary, and the study was conducted according to the tenets of the Helsinki Declaration.

The study instrument was an adapted WHO STEPS questionnaire for chronic disease risk factor surveillance (12). Trained research assistants administered the questionnaires. Information obtained included sociodemographic profile and self-reported cardiovascular risk factors related to tobacco use, alcohol consumption, dietary choices and physical activity. Each study participant had their weight and height measured using the Detecto PD300DHR Digital-ProDoc (USA) weighing scale and metre-rule, respectively. Participants 
were asked to empty their pockets and stand barefooted on the scale. Weight was recorded to the nearest $0.1 \mathrm{~kg}$. While still barefooted, each participant was asked to stand upright backing the meter-rule, feet together and head-dressing removed. The height was recorded to the nearest $0.1 \mathrm{~cm}$. The body mass index (BMI) was derived from the measured weight and height (13). The blood pressure of study participants was measured using Omron ${ }^{\circledR}$ BP-785 Intellisense sphygmomanometer in the sitting position thrice and the average documented.

\section{Definition of terms:}

Tobacco use:

- Ever smoked refers to an individual who has ever smoked cigarette, irrespective of the age of onset and current smoking status

- Current smoker refers to an individual who still smokes cigarette

- Second-hand smoker refers to an individual who has close relatives or friends who smoke in their presence.

- Pack-years smoked refers to the product of the number of packs of cigarette smoked per day and the number of years smoked.

Alcohol consumption:

- Alcoholic beverage refers to any alcoholic drink, whether beer, spirit or wine

- One unit of alcohol $(250 \mathrm{ml}$ of beer, or $30 \mathrm{mls}$ of spirit, or $100 \mathrm{mls}$ of wine) is equivalent to 8-10 grams of alcohol.

Obtained data from the filled questionnaires were entered into the Microsoft Excel spreadsheet from where it was exported to the Statistical Product and Service Solutions (SPSS) version 20.0 (SPSS Inc, Chicago, IL, USA) software for analysis. Numerical variables were summarized as percentages, means and standard deviation. The differences between categorical and means of continuous variables were analysed using chisquare test and independent t-test, respectively. The level of statistical significance was set at $\mathrm{p}<$ 0.05 .

\section{RESULTS}

Eight hundred and sixty-six adults were recruited for the study; 381 and 485 from the rural and urban setting, respectively. The male-to-female ratio of the study participants was 1:1 (rural) and 1.5:1 (urban). The mean age ( \pm standard deviation) in years of the rural dwellers (47.1 \pm 19.0 ) was significantly higher than the urban dwellers $(38.9 \pm 12.2),(\mathrm{t}=-7.332,95 \% \mathrm{CI}=$ 10.396 to $-6.004, \mathrm{p}<0.001)$. A significantly greater percentage of the study participants with primary level of education and less were rural dwellers. A greater proportion of the respondents in both urban (62.3\%) and rural (48.0\%) settings were married. None of the study participants who were rural dwellers had a professional or whitecollar job. Table 1 highlights the sociodemographic and biophysical characteristics of the study population.

\section{Tobacco Use}

Figure 1 shows the frequency and pattern of tobacco use among respondents.

About one-sixth of the respondents reported that they had ever smoked tobacco. The proportion of study participants who had smoked cigarette ever was significantly more among the rural dwellers (OR, 95\% CI: 0.310, 0.212-0.452; $<<0.001$ ).

Among study participants who had ever smoked, $81.4 \%(118 / 145)$ reported that they still smoke. A significantly higher percentage of the current smokers were rural dwellers (OR, 95\% CI: 0.254, $0.166-0.390 ; \mathrm{p}<0.001)$. The prevalence rate of current smokers who were males was significantly more than their female counterpart in both urban $(15.7 \%$ vs $1.0 \%, \mathrm{p}<0.001)$ and rural $(42.1 \%$ vs $3.1 \%, \mathrm{p}<0.001)$ settings.

Among the current smokers, the mean pack years $( \pm \mathrm{SD})$ smoked was $2.89( \pm 3.187)$ and $2.79( \pm 3.394)$ for rural and urban dwellers, respectively. The mean quantity of cigarette smoked by respondents in this study did not show any statistically significant rural-urban difference $(\mathrm{t}=-0.170,95 \% \mathrm{CI}:-1.225$ to 1.030 , $\mathrm{p}=0.865$ ).

About one-third of the respondents reported that they had close relatives and friends who smoke. A significantly higher proportion of the second-hand smokers were rural dwellers (OR, 95\% CI: 0.437, 0.325-0.587; $\mathrm{p}<0.001$ ).

About a fifth of the population consumes smokeless tobacco; rural more than urban dwellers (31.0\% vs 10.5\%). The observed difference in the proportion of smokeless tobacco users was significant (OR, 95\% CI: 0.262, 0.1820.376 ; $\mathrm{p}<0.001)$.

The prevalence of smokeless tobacco users who were males was significantly higher than their female counterpart in the urban $(20.9 \%$ vs $2.0 \%, \mathrm{p}<0.001)$ settings. In the rural setting, the prevalence of female smokeless tobacco users was higher than those of their male counterpart (30.4\% vs $26.3 \%$ ). Unlike the urban setting, the observed gender differences among rural 
dwellers was however not statistically significant $(\mathrm{p}=0.329)$

\section{Alcohol Consumption}

About two-thirds of the respondents reported that they had ever drunk alcohol, out of which 90\% (507/562) drank alcoholic beverages within the past 12 months. A significantly higher proportion of the rural dwellers drank alcohol in the past 12 months $(79.5 \%$ vs $42.1 \%, \mathrm{p}<0.001)$. (Figure 2)

A significantly higher percentage of the male $(264 ; 69.3 \%)$ compared with the female $(243 ; 50.1 \%)$ respondents reported they had drunk alcoholic beverages in the past 12 months $(p<0.001)$. A significantly higher proportion of both the male $(62.1 \%, \mathrm{p}<0.001)$ and female $(57.2 \%, \mathrm{p}<0.001)$ respondents who drank alcohol in the past 12 months were rural dwellers.

The average quantity of alcohol consumed in grams was higher in urban than rural dwellers [40.80 $( \pm 59.892)$ vs $38.16( \pm 28.218)]$. The difference in mean was not significant $(\mathrm{t}=$ $0.679,95 \% \mathrm{CI}:-4.991$ to $10.265, \mathrm{p}=0.497)$.

\section{Unhealthy Dietary Practices}

About one-third of the respondents add salt to already cooked food at the table. The proportion of rural and urban dwellers that use added salt did not differ significantly. (Table 2)

About three-quarters of the respondents eat less than five portions of fruits daily, out of which $18.7 \%(121 / 646)$ do not eat fruits at all. A significantly greater proportion of the respondents who eat less than five portions of fruits daily were rural dwellers ( $83.7 \%$ vs $67.4 \%$, $\mathrm{p}<0.001$ ). (Table 2)

The mean portion of fruits eaten per day was $3.29( \pm 2.225)$ and $2.87( \pm 1.700)$ for urban and rural dwellers, respectively. The urban-rural difference in average portion of fruits consumed daily was statistically significant $(t=3.057$, $95 \%$ CI: $0.151-0.691, \mathrm{p}=0.002$ ).

Majority of the respondents reported that they eat less than five portions of vegetables per day. This practice was more in rural compared with urban dwellers. (Table 2).

The average daily portions of vegetables consumed were $2.90( \pm 1.882)$ and $2.28( \pm 1.313)$ for urban and rural dwellers, respectively. The urban-rural difference in mean portions of vegetables eaten daily was significant $(\mathrm{t}=5.489$, $95 \%$ CI: $0.400-0.845, \mathrm{p}<0.001)$.

\section{Physical Inactivity/Sedentary Lifestyle}

In a typical week, $40.2 \%$ of the respondents do not walk or ride a bicycle continuously for at least 10 minutes to-and-from places; urban (47.6\%) more than rural (30.7\%) dwellers $(\mathrm{p}<0.001)$.

About one-third of the respondents engaged in recreational physical exercise in the last one month; urban (45.4\%) significantly more than rural $(15.2 \%)$ dwellers $(p<0.001)$. Figure 3

The average time spent watching television daily was $2.81( \pm 2.033)$ and $1.53( \pm 1.159)$ hours for urban and rural dwellers, respectively. The observed time difference was statistically significant $(\mathrm{t}=10.585,95 \%$ CI: 1.037 $-1.510, \mathrm{p}<0.001)$.

\section{DISCUSSION}

Lifestyle-related cardiovascular risk factors among adults in this study was common in both rural and urban settings. Although the rural setting in this study is sparsely populated and lack infrastructurally development, it has taken on the lifestyle that would have been hitherto prevalent only in cities and other urban areas. This reflects the influence on urbanization.

Tobacco smoking is a well-established behavioural risk factor for cardiovascular disease. The overall prevalence rate of current tobacco smoking of $13.6 \%$ in this study is higher than the estimated National and South-South prevalence of $3.9 \%$ and $2.7 \%$, respectively by the 2012 Global Adult Tobacco Survey (GATS) in Nigeria $(14,15)$. It will appear as if the frequency of tobacco smoking in Nigeria is rising due to urbanization and adoption of western lifestyle. The marked change between the prevalence of smoking in this study and the 2012 GATS may also be attributable to the gaps in the statutory framework to stop smoking in Nigeria. Although there is a National Tobacco Control Act of 2015, it lacks proper implementation (16-18). Thus, leaving tobacco use largely unchecked and on the rise in Nigeria. This is unlike some high-income countries where the rate of smoking has declined following adherence to stringent anti-tobacco use laws (19). In England, for example, the prevalence of current smokers dropped from $19.8 \%$ in 2011 to $14.9 \%$ in 2018 (20). About a third of the respondents in the index study were second-hand smokers, further increasing the proportion of persons at risk of cardiovascular disease from smoking. In a study of adult secondhand smokers in Abia State, South-East Nigeria, exposure to second-hand smoke was two times higher in public places than at home (21). Indeed, bearing in mind the large population of over 180 million, Nigeria could be ranked as a significant 
tobacco consuming nation (22).

Few previous studies in Nigeria compared the rural-urban differences in cigarette smoking $(15,23)$. The rural-urban difference in the prevalence rate of tobacco smoking in the index study is consistent with previous reports in which it was more in the rural than an urban setting $(15,23)$. The prevalence of smoking among the urban respondents in this study is comparable to the $7.1 \%$ obtained in another urban study in North-West, Nigeria (24). Although higher, the prevalence of smoking among respondents in the rural setting in this study is comparable to the $15.8 \%$ and $16.8 \%$ erstwhile reported respectively from rural dwellers in Delta and Edo States, South-South Nigeria $(25,26)$. In contrast, a much lower prevalence of current smoking (1.7\%) was obtained among adults in a rural setting in South-West Nigeria (27). This divergence may be as a result of the definitions of current smoking. While Oladapo et al. (27) defined current smokers strictly as those who smoke one or more sticks of cigarette daily for one year or more, the term was loosely defined in the index study as anyone who still smokes. By their definition, experimental smokers, non-daily smokers and those who have smoked for less than a year were inadvertently left uncaptured. The prevalence of smoking of $2.9 \%$ from a crosssectional study of adults in a rural community in Ekiti State, South-West, Nigeria was also far below the rate in the index study (28). Perhaps, the age difference in the populations studied may account for the observation. While the mean age was 42.5 years in the index study, it was 66.8 years in the Ekiti study. The prevalence of smoking declines with advancing age $(22,29)$. According to data from the World Health Organization (WHO), in 2015, the prevalence of current smoking among males and females in Nigeria was $17.4 \%$ and $1.1 \%$, respectively. Similar pattern of disproportionately higher prevalence of male smokers was observed in this study as with other studies across Nigeria $(21,24,27)$. The observed gender differences in the prevalence rate of smoking may be attributed to the widespread sociocultural disapproval of women who smoke.

The prevalence rate of alcohol consumption is high in this study, more so among males and rural dwellers. The sociocultural norms in many parts of Nigeria are tolerant to alcohol consumption (30). For example, in Delta State where the index study was carried out, it is commonplace to find locally brewed alcoholic beverages (aka kain-kain, Sapele water) consumed for pleasure, as part of traditional rites or as solvents for herbal-based remedies for diverse ailments.

The association between the intake of alcoholic beverages and cardiovascular disease is intricate (31). While the consumption of large quantities of alcohol is detrimental to heart health, there are varying reports on the light-tomoderate intake (32-34). In the index study, the clear majority of those who consume alcohol were not heavy drinkers. However, recall bias and intentional under-reporting of the usual quantity of alcohol consumed cannot be ruled out, especially as heavy drinking to the extent of getting drunk is frowned at and considered as a sociocultural taboo in the study area.

Dietary choices are closely linked to risk of heart disease $(35,36)$. Consumption of at least five servings / portions of fruits and vegetables every day is linked to reduced risk of heart disease and stroke $(37,38)$. Adequate consumption of fruits and vegetables is poor in this study, more so in the rural setting. About a quarter of the study population consumed at least five servings / portions of fruits while about onetenth ate at least five portions of vegetables daily. Eating pattern is closely linked to socio-cultural ties (39). The majority $(84.5 \%)$ of the rural population are Urhobos, and their traditional soups are palm-oil based rather than vegetablebased. It was therefore not surprising in this study that most of the respondents, especially the rural dwellers ate less than the recommended quantities of fruits and vegetables. Also, it is not unlikely that urban dwellers have more access to health information and the benefits of consumption of fruits and vegetables, especially as it pertains to cardiovascular health.

Increased risk of cardiovascular disease is also associated with the intake of high dietary sodium more than $2 \mathrm{~g}$ per day (40). Consumption of processed foods and natural foods with added table salt increase intake of sodium to harmful levels. About one-third of the respondents in the index study reported that they often add salt to already cooked food. There was no rural-urban difference in this dietary practice.

The prevalence of physical inactivity/sedentary lifestyle in the index study was high. A previous study has also reported a high prevalence of physical inactivity in Nigeria (41). The index study assessed recreational exercises and physical activity related to transportation. Both forms of physical activities significantly varied with the place of residence. Whereas almost half of the urban respondents do not walk or cycle continuously for 10 minutes as a means of transportation, about two-thirds of the 
rural respondents do. On the other hand, more urban than rural dwellers engage in recreational physical activities. Although the index study did not assess work-related physical activity, previous reports have shown that this form of physical activity is also low among Nigerians $(28,42)$.

\section{CONCLUSION}

Overall, lifestyle-related cardiovascular risk factors were prevalent in this study more in the rural than urban setting. Although the barriers to heart-healthy lifestyle were not assessed in this paper, the need to strengthen health education and health promotion activities aimed at reducing lifestyle-related cardiovascular risk factors is expedient. These activities should not be limited to individual contacts but must include other ecological levels in the community such as schools, workplace, corporate and faith-based organizations. Stakeholders in the cardiovascular community should engage government and guide local policy formulation geared towards achieving a healthy lifestyle for the general population.

Conflict of Interest: The author has no conflict of Interest to declare. However, the abstract of this paper was presented orally at the $46^{\text {th }}$ Annual General and Scientific Meeting (AGSM) of the Nigerian Cardiac Society in 2017.

\section{REFERENCES}

1. World Health Organization (WHO) 2018. Factsheet: Cardiovascular disease (Last updated 17 May 2017). Available from: http://www.who.int/en/news-room/factsheets/detail/cardiovascular-diseases-(cvds) (Accessed on 27/11/2018)

2. Benjamin EJ, Virani SS, Callaway SW, Chamberlain AM, Chang AR, Cheng S, et al., on behalf of the American Heart Association Council on Epidemiology and Prevention Statistics Committee and Stroke Statistics Subcommittee. Heart disease and stroke statistics -2018 Update: A report from the American Heart Association. Circulation 2018;137(12):e67e492. doi: 10.1161/CIR.0000000000000558

3. Keates AK, Mocumbi AO, Ntsekhe M, Sliwa K, Stewart S. Cardiovascular disease in Africa: epidemiological profile and challenges. Nat Rev Cardiol. 2017;14(5):273-293. doi: 10.1038/nrcardio.2017.19

4. Roth GA, Huffman MD, Moran AE, Feigin V, Mensah GA, Naghavi M, et al. Global and Regional Patterns in Cardiovascular Mortality From 1990 to 2013. Circulation 2015;132:16671678 . d o i : 10.1161/CIRCULATIONAHA.114.008720.
5. Yeates K, Lohfeld L, Sleeth J, Morales F, Rajkotia Y, Ogedegbe O. A global perspective on cardiovascular disease in vulnerable populations. Can J Cardiol 2015;31(9):1081-1093

6. Gersh BJ, Sliwa K, Mayosi BM, Yusuf S. The epidemic of cardiovascular disease in the developing world: global implications. Eur Heart J 2010;31:642-648. doi : 10.1093/eurheartj/ehq030

7. Mensah GA, Wei GS, Sorlie PD, Fine LJ, Rosenberg Y, Kaufmann PG, et al. Decline in cardiovascular mortality: possible causes and implications. Circ Res 2017;120(2):366-380. doi:10.1161/CIRCRESAHA.116.309115

8. Silwa K, Acquah L, Gersh BJ, Mocumbi AO. Global Burden of Cardiovascular Disease: Impact of Socioeconomic Status, Ethnicity, and Urbanization on Risk Factor Profiles of Cardiovascular Disease in Africa. Circulation. 2016;133:1199-1208. doi: 10.1161/ CIRCULATIONAHA.114.008730.

9. Yusuf S, Reddy S, Ounpuu S, Anand S. Global burden of cardiovascular diseases. Part I: General considerations, the epidemiologic transition, risk factors, and impact of urbanization. Circulation $2001 ; 104$ ( 22 ): $2746-2753$.d D o i : abs/10.1161/hc4601.099487

10. Smith, S. et al., 2012. Urbanization and cardiovascular disease: Raising heart-healthy children in today's cities. [pdf] Geneva: The World Heart Federation. Available at: https://www.world-heart-federation.org/wpcontent/uploads/2017/05/FinalWHFUrbanizatio nLoResWeb.pdf(Accessed on 27/11/2018)

11. Ogah OS, Okpechi I, Chukwuonye II, Akinyemi JO, Onwubere BJC, Falase AO, Stewart S, Silwa $\mathrm{K}$. Blood pressure, prevalence of hypertension and hypertension related complications in Nigerian Africans: A review. World J Cardiol 2012; 4(12): 327-340

12. World Health Organization. The WHO Stepwise approach to chronic disease risk factor surveillance (STEPS): 2003, Geneva, Switzerland. Ava ilable at: http://www.who.int/chp/steps/STEPS_Instrume nt_v2.1.pdf

13. Garrow JS, Webster J. Quetelet's index $\left(\mathrm{W} / \mathrm{H}^{2}\right)$ as a measure of fatness. Int J Obes 1985;9:147-153

14. Adeniji F, Bamgboye E, van Walbeek C. Smoking in Nigeria: Estimates from the Global Adult Tobacco Survey (GATS). Journal of Scientific Research \& Reports 2016;11(5):1-10

15. Global Adult Tobacco Survey (GATS), Nigeria 2012: Factsheet. Available at: http://www.who.int/tobacco/surveillance/survey /gats/nigeria_factsheet.pdf?ua=1 (last accessed on $05 / 12 / 2018$ )

16. Report card on the WHO Framework Convention on Tobacco Control, Nigeria. http://www.afro.who.int/sites/default/files/2017 -09/Nigeria_report_card_0.pdfAct, 2015.

17. Federal Republic of Nigeria Official Gazette 
2015;102(70):A181-A208. Available at: https://www.tobaccocontrollaws.org/files/live/N igeria/ Nigeria \% 20 - \% 20 T C A \% 20 $\% 20$ national.pdf. (last accessed on 05/12/2018)

18. WHO report on the global tobacco epidemic, 2017 Country profile: Nigeria. Available from: http://www.who.int/tobacco/surveillance/policy /country_profile/nga.pdf?ua $=1$ (accessed on 05/12/2018)

19. World Health Organization. Tobacco control country profiles. Geneva, Switzerland: World $\mathrm{Hea} 1 \mathrm{th}$ Organization; 2015 . http://www.who.int/tobacco/surveillance/policy /country profile/en/

20. National Health Service (NHS) Digital. Statistics on Smoking - England, 2018 [PAS]. Part 3: Smoking patterns among adults. Available at: h t t p s : / / digita l. n h s . uk/data-and information/publications/statistical/statisticson-smoking/statistics-on-smoking-england2018/part-3-smoking-patterns-in-adults (accessed on 27/05/2019)

21. Onyeonoro UU, Ukegbu AU, Chukwuonye II, Madukwe OO, Akhimien MO, Ogah OS. Prevalence and pattern of secondhand smoking in Abia State, Nigeria. Nig J Cardiol 2016;13:119-124

22. Ng M, Freeman MK, Fleming TD, Robinson M, Dwyer-Lindgren L, Thomson B, et al. Smoking prevalence and cigarette consumption in 187 countries, 1980-2012. JAMA 2014;311:183-192

23. Ibrahim BS, Usman R, Niyang M, Gobir B, Okon U. Prevalence and determinants of tobacco use in Nigeria: A one-year review, 2014. International Journal of Scientific and Engineering Research 2017;8(3):873-877

24. Kaoje AU, Sabir AA, Yusuf S, Jimoh AO, Raji $\mathrm{MO}$, Ango UM, et al. Tobacco consumption prevalence and pattern among residents of Sokoto metropolis northwest Nigeria. East Afr Journal of public health 2015;12:981-987.

25. Ibekwe RU. Modifiable risk factors of hypertension and socio-demographic profile in Oghara, Delta State; prevalence and correlates. Ann Med Health Sci Res 2015;5(1):71-77

26. Omuemu VO, Okojie OH, Omuemu CE. Sociodemographic correlates of modifiable risk factors for hypertension in a rural community in Edo State, Nigeria. J Community Med Prim Health Care 2008; 20:25-34

27. Oladapo OO, Falase AO, Salako L, Sodiq O, Shoyinka K, Adedapo K. Cardiovasc J Afr 2010;21:26-31.

28. Ogunmola OJ, Olaifa AO, Oladapo OO, Babatunde OA. Prevalence of cardiovascular risk factors among adults without obvious cardiovascular disease in a rural community in Ekiti State, Southwest Nigeria. BMC Cardiovasc Disord 2013;13:89. Doi: 10.1186/1471-2261-1389

29. Kleykamp BA, Heishman SJ. The older smoker. JAMA2011;306:876-877
30. Dumbili E. Changing Patterns of Alcohol Consumption in Nigeria: An Exploration of Responsible factors and Consequences. A Journal of the BSA MedSoc Group 2013;7(1):2033

31. Conen D. Alcohol consumption and incident cardiovascular disease: not just one unifying hypothesis. Eur Heart J 2015;36:897-898. doi:10.1093/eurheartj/ehv021

32. Rehm J, Mathers C, Popova S, Thavorncharoensap M, Teerawattananon Y, Patra J. Alcohol and Global Health 1: Global burden of disease and injury and economic cost attributable to alcohol use and alcohol-use disorders. Lancet 2009; 373: 2223-2233

33. Ronksley PE, Brien SE, Turner BJ, Mukamal KJ, Ghali WA. Association of alcohol consumption with selected cardiovascular disease outcomes: a systematic review and meta-analysis. BMJ 2011;342:d671. doi: 10.1136/bmj.d671

34. Whitman IR, Agarwal V, Nah G, Dukes JW, Vittinghoff E, Dewland TA, et al. Alcohol abuse and cardiac disease. J Am Coll Cardiol $2017 ; 69(1): 13-24$. d o i : 10.1016/j.jacc.2016.10.048

35. Eilat-Adar S, Sinai T, Yosefy C, Henkin Y. Nutritional Recommendations for cardiovascular disease prevention. Nutrients 2013;5:3646-3683. doi: 10.3390/nu5093646

36. Holmberg S, Thelin A, Stiernstrom E. Food choices and coronary heart disease: A population based cohort study of rural Swedish men with 12 years of follow-uo. Int J Environ Res Public Health 2009;6(10):2626-2638. doi: 10.3390/ijerph6102626

37. He FJ, Nowson CA, Lucas M, MacGregor GA. Increased consumption of fruit and vegetables is related to a reduced risk of coronary heart disease: meta-analysis of cohort studies. J Hum Hypertens 2007;21(9):717-728

38. Wang X, Ouyang Y, Liu J, Zhu M, Zhao G, Bao $\mathrm{W}$, et al. Fruit and vegetable consumption and mortality from all causes, cardiovascular disease, and cancer: systematic review and dose-response meta-analysis of prospective cohort studies. BMJ 2014;349:g4490. doi: 10.1136/bmj.g4490

39. Higgs S, Thomas J. Social influences on eating. Current Opinion in Behavioural Sciences 2016;9:1-6. doi: 10.1016/j.cobeha.2015.10.005

40. World Health Organization (WHO), Guideline: Sodium intake for adults and children. Geneva, World Health Organization (WHO), 2012

41. Adegoke BO, Oyeyemi AL. Physical inactivity in Nigerian young adults: prevalence and sociodemographic correlates. J Phys Act Health 2011;8(8):1135-1142.

42. Oyeyemi AL, Adeyemi O. Relationship of physical activity to cardiovascular risk factors in an urban population of Nigerian adults. Arch Public Health 2013;71(1):6. doi: 10.1186/07787367-71-6 
Table 1. Socio-demographic and biophysical profile of study participants

\begin{tabular}{|c|c|c|c|c|}
\hline \multirow[t]{2}{*}{ Variable } & \multirow[t]{2}{*}{ Category } & \multicolumn{2}{|c|}{ Setting of Study Location } & \multirow[t]{2}{*}{$\mathrm{p}$-value } \\
\hline & & $\begin{array}{l}\text { Urban } \\
\mathrm{n}=485(\%)\end{array}$ & $\begin{array}{l}\text { Rural } \\
\mathrm{n}=381(\%)\end{array}$ & \\
\hline \multirow[t]{2}{*}{ Sex } & Male & $191(50.1)$ & $190(49.9)$ & \multirow[t]{2}{*}{0.002} \\
\hline & Female & $294(60.6)$ & $191(39.4)$ & \\
\hline \multirow{5}{*}{$\begin{array}{l}\text { Age Group } \\
\text { (years) }\end{array}$} & $<35$ & $180(59.2)$ & $124(40.8)$ & \multirow[t]{5}{*}{$<0.001$} \\
\hline & $35-44$ & $158(73.8)$ & $56(26.2)$ & \\
\hline & $45-54$ & $84(55.3)$ & $68(44.7)$ & \\
\hline & $55-64$ & $48(52.7)$ & $43(47.3)$ & \\
\hline & $\geq 65$ & $15(14.3)$ & $90(85.7)$ & \\
\hline \multirow{7}{*}{$\begin{array}{l}\text { Marital } \\
\text { Status }\end{array}$} & Single & $118(69.0)$ & $53(31.0)$ & \multirow[t]{7}{*}{$<0.001$} \\
\hline & Married & $302(62.3)$ & $183(37.7)$ & \\
\hline & Widowed & $12(30.8)$ & $27(69.2)$ & \\
\hline & Separated & $4(9.5)$ & $38(90.5)$ & \\
\hline & Divorced & $2(66.7)$ & $1(33.3)$ & \\
\hline & Cohabiting & $28(31.5)$ & $61(68.5)$ & \\
\hline & $\mathrm{N} / \mathrm{A}$ & 19 & 18 & \\
\hline \multirow{6}{*}{$\begin{array}{l}\text { Educational } \\
\text { Status }\end{array}$} & No Formal/ Less than Primary & $15(12.2)$ & $108(87.8)$ & \multirow[t]{6}{*}{$<0.001$} \\
\hline & Completed Primary & $50(25.6)$ & $145(74.4)$ & \\
\hline & Completed Secondary & $242(67.6)$ & $116(32.4)$ & \\
\hline & Completed Tertiary & $120(98.4)$ & $2(1.6)$ & \\
\hline & Postgraduate & $40(100.0)$ & $0(0.0)$ & \\
\hline & N/A & 18 & 10 & \\
\hline \multirow[t]{5}{*}{ Occupation } & Professional & $35(100.0)$ & $0(0.0)$ & \multirow[t]{5}{*}{$<0.001$} \\
\hline & White Collar & $76(100.0)$ & $0(0.0)$ & \\
\hline & Blue Collar & $260(45.0)$ & $318(55.0)$ & \\
\hline & Student & $45(45.0)$ & $55(55.0)$ & \\
\hline & Unemployed/Retired & $69(89.6)$ & $8(10.4)$ & \\
\hline \multirow[t]{10}{*}{ Ethnicity } & Edo & $34(82.9)$ & $7(17.1)$ & \multirow[t]{10}{*}{$<0.001$} \\
\hline & Hausa & $8(61.5)$ & $5(38.5)$ & \\
\hline & Igbo & $96(93.2)$ & $7(6.8)$ & \\
\hline & Ijaw & $33(84.6)$ & $6(15.4)$ & \\
\hline & Isoko & $52(88.1)$ & $7(11.9)$ & \\
\hline & Itsekiri & $24(88.9)$ & $3(11.1)$ & \\
\hline & Okpe & $9(50.0)$ & $9(50.0)$ & \\
\hline & Urhobo & $187(36.7)$ & $322(63.3)$ & \\
\hline & Yoruba & $27(87.1)$ & $4(12.9)$ & \\
\hline & Others & $15(57.7)$ & $11(42.3)$ & \\
\hline $\begin{array}{l}\text { Body Mass } \\
\text { Index } \\
\left(\mathrm{kg} / \mathrm{m}^{2}\right)\end{array}$ & Mean $( \pm \mathrm{SD})$ & $\begin{array}{l}24.98 \\
( \pm 5.584)\end{array}$ & $\begin{array}{l}23.05 \\
( \pm 6.924)\end{array}$ & $<0.001$ \\
\hline $\begin{array}{l}\text { Mean } \\
\text { Blood }\end{array}$ & Systolic & $\begin{array}{l}126.08 \\
( \pm 14.941)\end{array}$ & $\begin{array}{l}123.52 \\
( \pm 17.118)\end{array}$ & 0.019 \\
\hline \multirow[t]{2}{*}{$\begin{array}{l}\text { Pressure } \\
(\mathrm{mmHg})\end{array}$} & Diastolic & $\begin{array}{l}78.41 \\
( \pm 11.260)\end{array}$ & $\begin{array}{l}72.33 \\
( \pm 13.086)\end{array}$ & $<0.001$ \\
\hline & Pulse Pressure & $47.82( \pm 11.377)$ & $\begin{array}{l}51.28 \\
( \pm 15.162)\end{array}$ & $<0.001$ \\
\hline
\end{tabular}


Table 2. Rural-Urban differences in the prevalence of unhealthy dietary practices

\begin{tabular}{|c|c|c|c|c|c|c|}
\hline Variable & Category & $\begin{array}{l}\text { Frequency } \\
\mathrm{N}=866 \\
(\%)\end{array}$ & $\begin{array}{l}\text { Urban } \\
\mathrm{n}=485(\%)\end{array}$ & $\begin{array}{l}\text { Rural } \\
\mathrm{n}=381(\%)\end{array}$ & $\begin{array}{l}\text { Odds ratio } \\
(95 \% \mathrm{CI})\end{array}$ & p-value \\
\hline \multirow{2}{*}{$\begin{array}{l}\text { Add salt on-table to } \\
\text { your already } \\
\text { cooked food }\end{array}$} & Yes & $\begin{array}{l}262 \\
(30.3)\end{array}$ & $150(30.9)$ & $112(29.4)$ & \multirow[t]{2}{*}{$\begin{array}{l}1.075 \\
(0.803-1.441)\end{array}$} & \multirow[t]{2}{*}{0.626} \\
\hline & No & $\begin{array}{l}604 \\
(69.7)\end{array}$ & $\begin{array}{l}335 \\
(69.1)\end{array}$ & $\begin{array}{l}269 \\
(70.6)\end{array}$ & & \\
\hline \multirow[t]{2}{*}{$\begin{array}{l}\text { Portions of fruits } \\
\text { eaten daily }\end{array}$} & $<5$ & $\begin{array}{l}646 \\
(74.6)\end{array}$ & $327(67.4)$ & $319(83.7)$ & \multirow[t]{2}{*}{$\begin{array}{l}0.402 \\
(0.289-0.560)\end{array}$} & \multirow[t]{2}{*}{$<0.001$} \\
\hline & $\geq 5$ & $\begin{array}{l}220 \\
(25.4)\end{array}$ & $\begin{array}{l}158 \\
(32.6)\end{array}$ & $\begin{array}{l}62 \\
(16.3)\end{array}$ & & \\
\hline $\begin{array}{l}\text { Portions of leafy } \\
\text { vegetables eaten }\end{array}$ & $<5$ & $\begin{array}{l}771 \\
(89.0)\end{array}$ & $403(83.1)$ & 368 (96.6) & \multirow[t]{2}{*}{$\begin{array}{l}0.174 \\
(0.095-0.317)\end{array}$} & \multirow[t]{2}{*}{$<0.001$} \\
\hline daily & $\geq 5$ & $\begin{array}{l}95 \\
(11.0)\end{array}$ & $82(16.9)$ & $\begin{array}{l}13 \\
(3.4)\end{array}$ & & \\
\hline Physical Activity & $\begin{array}{l}\text { Recreational } \\
\text { exercise in last } \\
\text { month }\end{array}$ & $\begin{array}{l}278 \\
(32.1)\end{array}$ & $220(45.4)$ & $\begin{array}{l}58 \\
(15.2)\end{array}$ & $\begin{array}{l}4.623 \\
(3.318-6.442)\end{array}$ & $<0.001$ \\
\hline
\end{tabular}

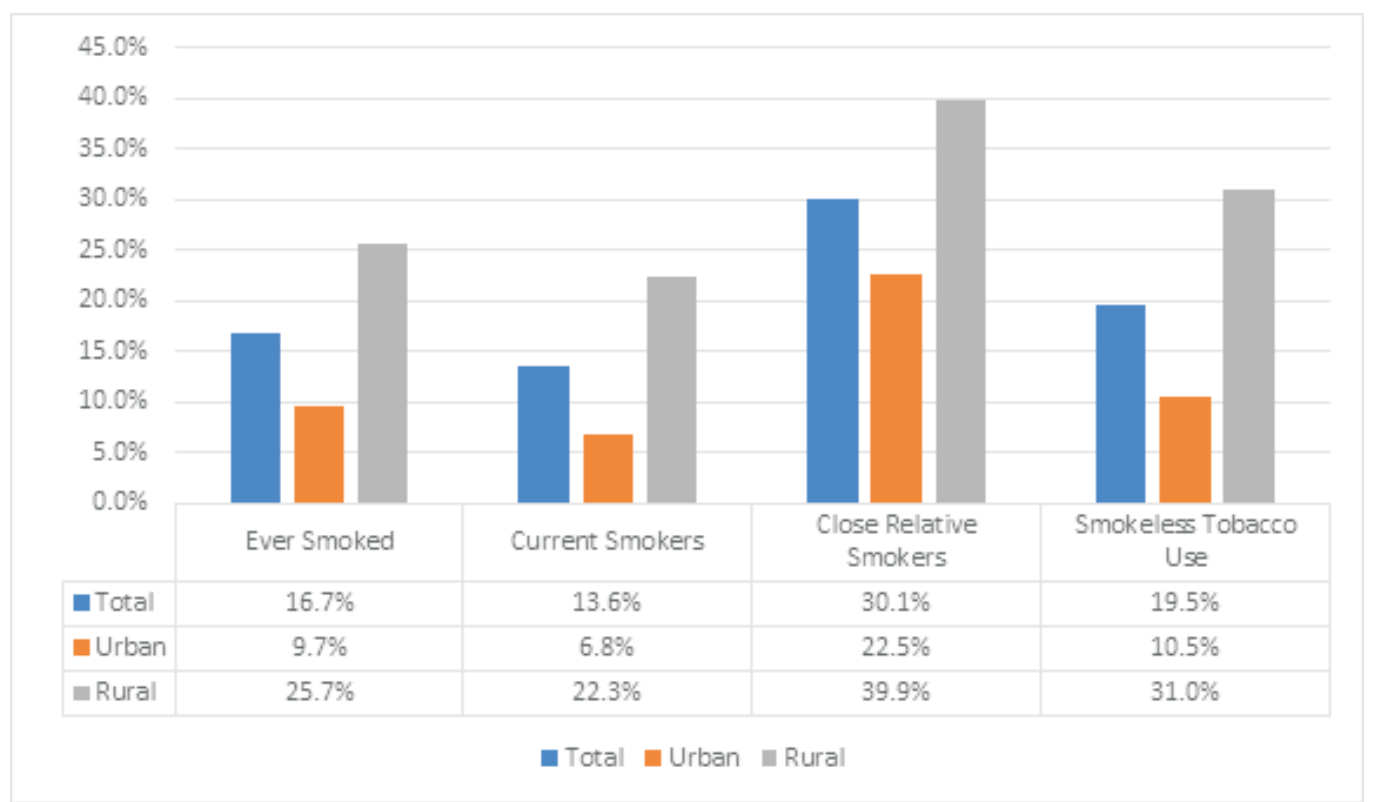

Figure 1. Frequency and pattern of tobacco use among respondents 


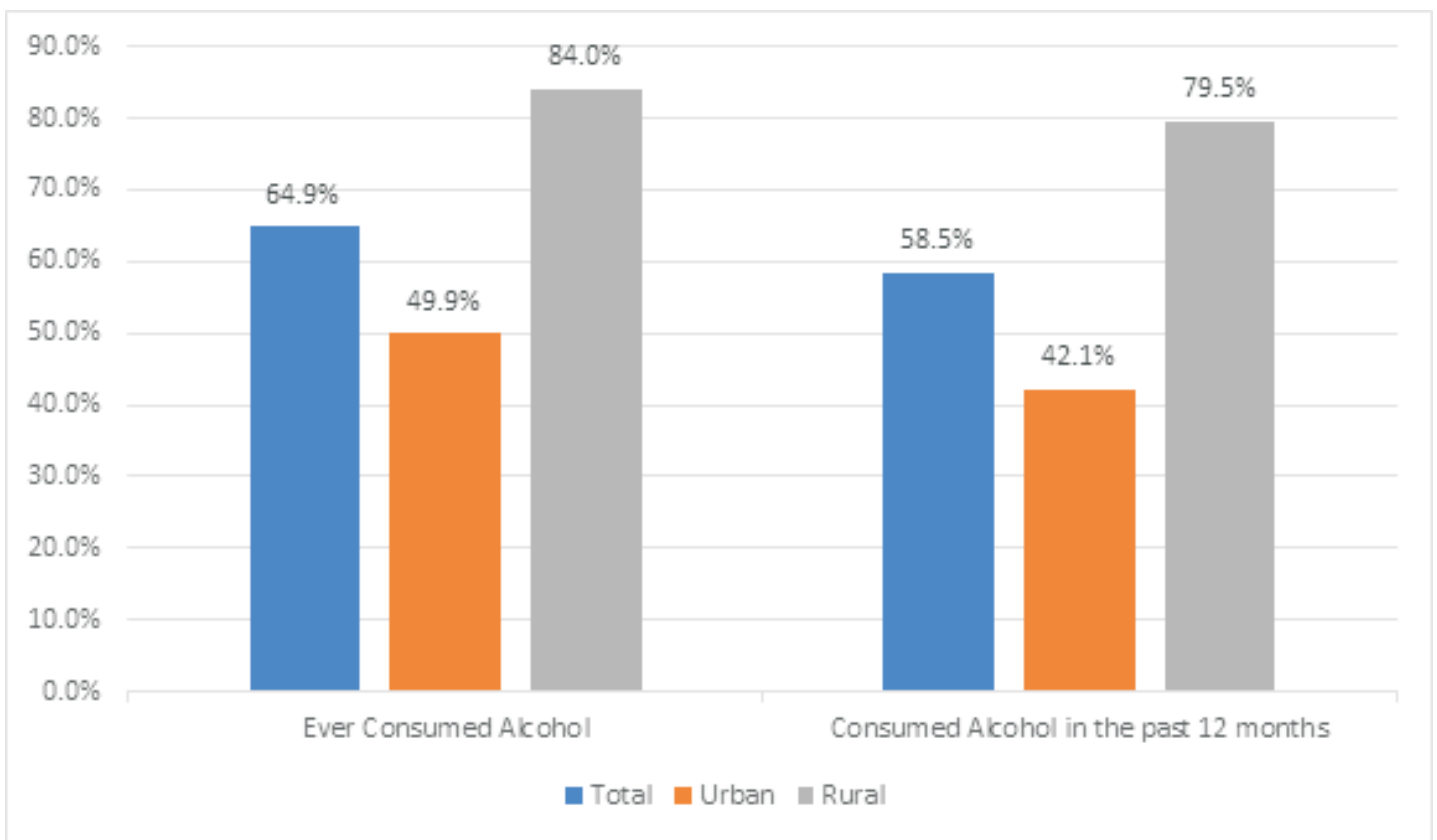

Figure 2. Prevalence and urban-rural distribution of alcohol consumption

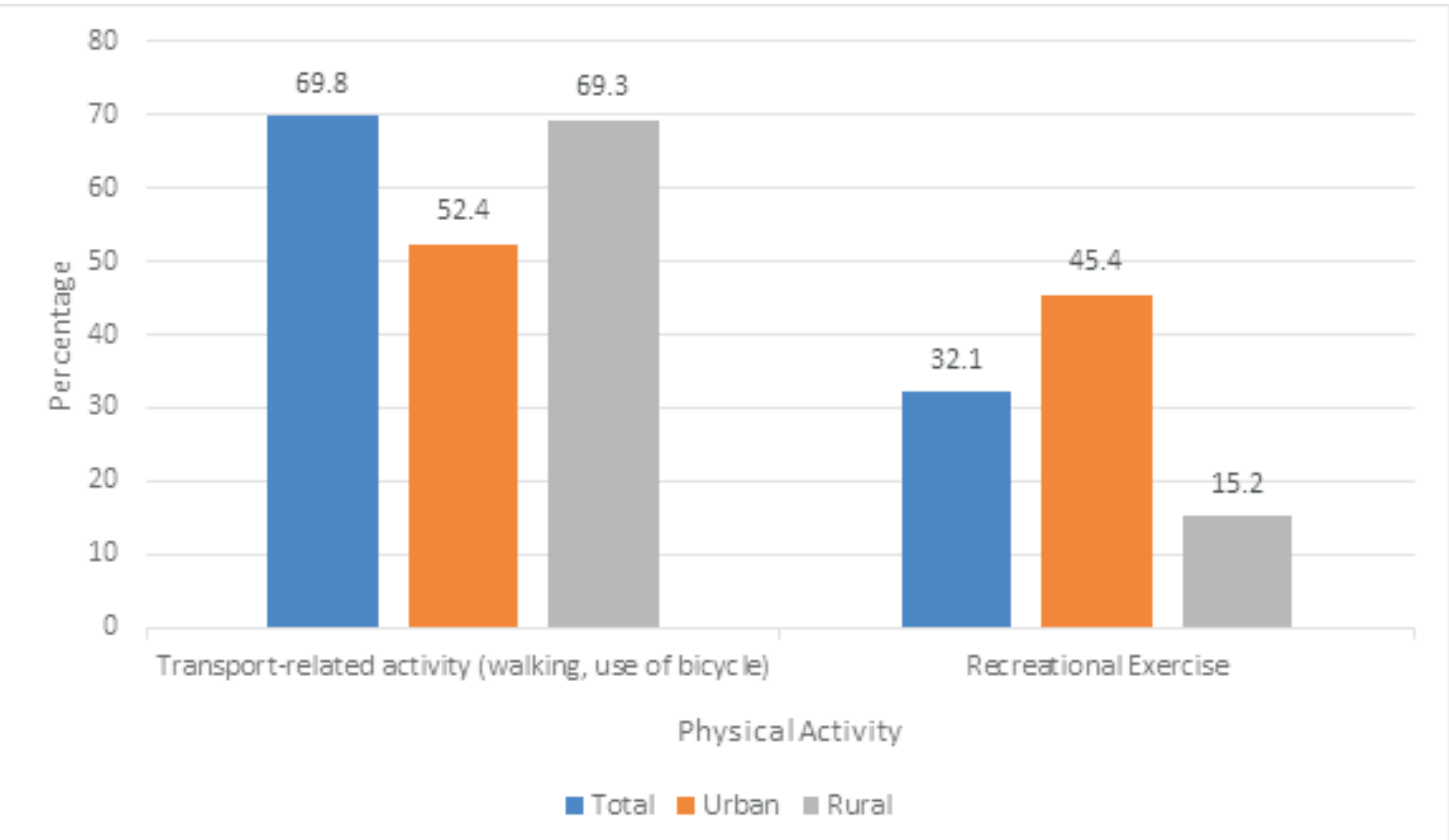

Figure 3. Prevalence of transport-related and recreational physical activity among respondents 